\title{
The Method and Timing of Weed Control Affect the Productivity of Intercropped Maize (Zea mays L.) and Bean (Phaseolus vulgaris L.)
}

\author{
Sabine Andert (D)
}

check for updates

Citation: Andert, S. The Method and Timing of Weed Control Affect the Productivity of Intercropped Maize (Zea mays L.) and Bean (Phaseolus vulgaris L.). Agriculture 2021, 11, 380. https://doi.org/10.3390/ agriculture11050380

Academic Editor: Roberto Mancinelli

Received: 7 April 2021

Accepted: 21 April 2021

Published: 23 April 2021

Publisher's Note: MDPI stays neutral with regard to jurisdictional claims in published maps and institutional affiliations.

Copyright: (C) 2021 by the author. Licensee MDPI, Basel, Switzerland. This article is an open access article distributed under the terms and conditions of the Creative Commons Attribution (CC BY) license (https:// creativecommons.org/licenses/by/ $4.0 /)$.
Crop Health, Faculty of Agricultural and Environmental Sciences, University of Rostock, Satower Straße 48, 18051 Rostock, Germany; sabine.andert@uni-rostock.de

\begin{abstract}
Intercropping results in high overall system productivity on a given piece of land due to the efficient use of available plant growth resources. Weed control in intercropping systems is, however, still a challenge. This study focuses on the effect of the type of weed control (chemical/mechanical) and the timing of chemical herbicide application (pre-emergence/post-emergence) on weed control and crop productivity in a maize bean mixture. For this purpose, the results of a three-year field experiment (2017 to 2019) in northeast Germany will be presented. The experimental setup included a control, three chemical methods, and one mechanical method of weed control. Except for the mechanical treatment, a completely randomized block design was established. Weeds were assessed at $\mathrm{BBCH} 12$ of the maize, immediately before the first weed control treatments to estimate the initial weed infestation, and twice in the six to eight leaf stage of the maize. The weed coverage (\%) was estimated. The maize bean mixture was harvested and yields $\left(\mathrm{tha}^{-1}\right)$ were measured. The results confirm that the type of weed control, as well as the timing of herbicide application, significantly affects the weed coverage of the maize bean mixture. The most successful weed control strategy was the double chemical herbicide application, in which chemical herbicides are in used pre-emergence beans (BBCH 12 maize) and post-emergence beans (BBCH 12 bean). Weed coverage was reduced by up to $75 \%$ using this most effective herbicide strategy and by up to $61 \%$ through mechanical weed control, compared to the control. The additional effects of post-emergence treatment on the pre-emergence herbicide control resulted in a $16.5 \%$ weed coverage decline. The yield surplus of double chemical herbicide application (pre/post-emergence) was up to 53\%, and for the mechanical weed control up to $23 \%$. Additionally, post-emergence herbicide use in intercropped maize and bean resulted in a $16 \%$ yield surplus, compared to the single pre-emergence chemical weed control. Optimal timing of weed control during the most sensitive phenology stages of the maize bean mixture is crucial for productivity. The results of this study provide an additional option for suitable weed control of intercropped maize and bean.
\end{abstract}

Keywords: intercropping; chemical herbicide use; mechanical weed control; pre/post-emergence herbicide application

\section{Introduction}

Sustainable development is one of the fundamental objectives of the European Union (EU). Thus, sustainable governing processes have emerged in the EU and its member states. In 2009, the EU adopted the Renewable Energy Directive, which is one of the most important regulations for sustainability in relation to biofuels (European Directive 2009/28/EC). Biomass-derived energy carriers, such as biofuels, biogas, biodiesel, and bioethanol have been a particularly important and versatile renewable energy source worldwide. It is expected to play a leading role in the transformation of the energy supply to renewable energy [1,2].

Due to its high biomass and energy yields, silage maize is the most important cosubstrate in biogas production [3,4]. The high proportion of arable land devoted to maize 
(Zea mays L.) production, however, may cause some serious environmental concerns [5]. Conventional maize monoculture is particularly criticized for environmental reasons, e.g., soil erosion, nitrate leaching, phytosanitary risks, and excessive irrigation [6].

Intercropping is highlighted as one of the efficient cropping systems that increase the overall system productivity on a given piece of land due to efficient use of the available plant growth resources [7-9]. Nutrients, water, and light can be used more effectively by mixtures and contribute to an increase in yields or yield stability [10-12].

Intercropping with maize and the common bean (Phaseolus vulgaris L.) is one of the widely used practices of producing food crops on smallholder farms [13], especially since the intercropped cultivation system ensures avoidance of risks associated with complete crop failure [14]. Moreover, mixed intercropping with perennial grasses/legumes and winter wheat/red clover are already widely implemented in industrialized agricultural landscapes [15], even though intercropped maize and bean has been suggested as an alternative cropping system with environmental benefits $[16,17]$. The common bean improves soil fertility through fixation of atmospheric nitrogen in symbiosis with rhizobia [18,19].

Generally, intercropping has been shown to reduce the risks of pests, especially the infestation of weeds, while intercrops can utilize available resources more effectively than separately grown crops. This results in a reduction of the number of resources that are available to weeds [9,20-22]. Effective weed control in intercropped maize and bean is necessary to minimize yield losses due to weeds. Weed management is, however, still a challenge in intercropped systems [16,23] for both conventional and organic cropping systems. Intercropping a dicotyledonous crop with a monocotyledonous crop reduces the number of possible herbicides that can be used for chemical control [15]. Currently, there are only three active ingredients that are registered in Germany: pendimethalin, dimethenamid-P, and clomazone [24]. All three active ingredients are registered as preemergence herbicides. The application of the pre-emergence herbicides is an established method to control a weed, maize, and bean mixture $[25,26]$. However, pre-emergence herbicide use provides merely suboptimal weed control of late-emerging weeds [25]. Preemergence herbicide application followed by one mechanical weed control results in a higher weed control efficiency [27]. Nevertheless, mechanical weed control management in intercropped maize and bean is limited due to the different sowing dates, emergence times of the two crops, and, particularly, soil characteristics such as soil texture and soil moisture content. Weed control of late-emerging weeds by using post-emergence herbicides might be an alternative method in intercropped maize and bean.

Currently available studies fail to measure the effect of post-emergence herbicide application in maize bean mixtures [25,27]. This study focuses on the effect of postemergence herbicide use in intercropped maize and bean. For this purpose, the type of weed control (chemical/mechanical) and the timing of chemical herbicide use (pre/postemergence) on the weed infestation in intercropped maize and bean was analyzed.

Post-emergence herbicide control is mainly used for the control of annual grasses. It will be still hypothesized that the post-emergence herbicide use, additionally to preemergence treatments, might be suitable to minimize the overall weed infestation in intercropped maize and bean.

\section{Materials and Methods}

\subsection{Sampling Sites}

In the years 2017 to 2019, a field trial was set up in northeast Germany (location "Rostock": $12^{\circ} 07^{\prime} \mathrm{E}, 54^{\circ} 05^{\prime} \mathrm{N}$ ) (Figure 1). The experimental field was located $15 \mathrm{~km}$ away from the Baltic Sea coast at $45 \mathrm{~m}$ above sea level [28]. The mean annual temperature between 1981 and 2010 was $9.2{ }^{\circ} \mathrm{C}$ with mean annual precipitation of $646 \mathrm{~mm}$. The soil type is loamy sand. 


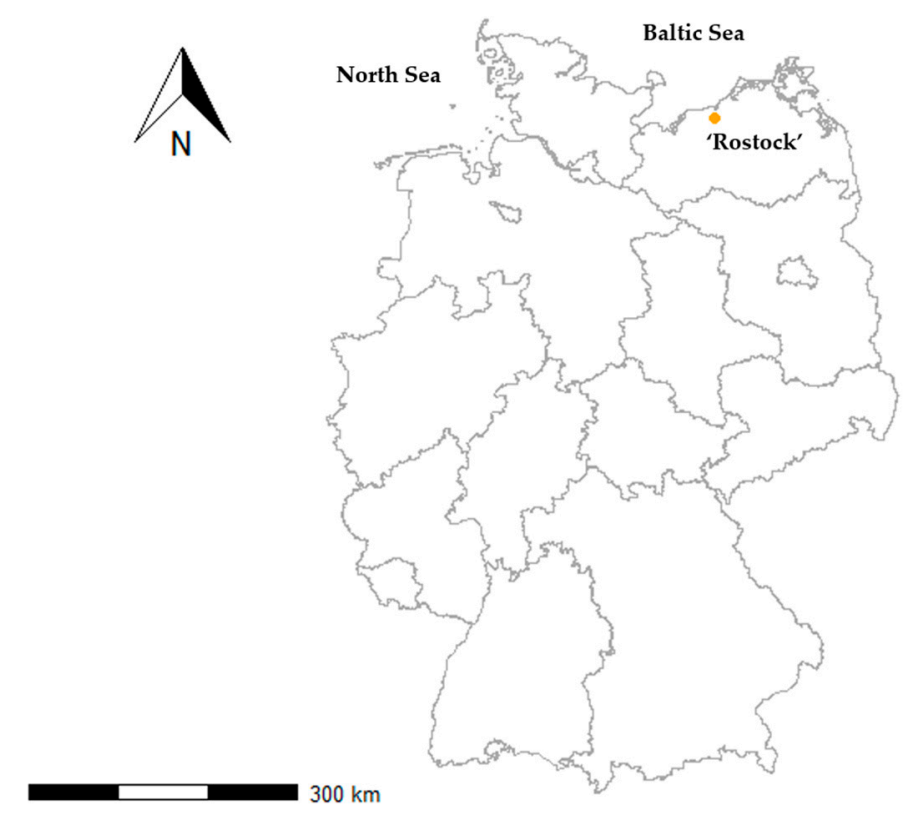

Figure 1. Location of "Rostock" in northeast Germany.

The local weather conditions of "Rostock" are favorable for common bean cultivation due to the moderate maritime climate. Fairly cool springs/summers and plentiful rainfall seems to increase seed quality mainly through increasing the maximum quality attainable during the course of crop development [29]. The average yield (2012 to 2017) level of the common bean (main crop) from the Rostock area (federal state Mecklenburg-Western Pomerania) is higher compared to the average bean yield in northeast Germany [30].

The crop management of intercropped maize and bean was similar among the three experimental years (Table 1). Maize (variety Sofala DUO) was sown at the end of April or the beginning of May depending on weather conditions in the three experimental years. Maize seeds were treated with the insecticide Flowsan FS ${ }^{\circledR}$ (active ingredient Thiram) and the fungicide Influx $X \mathrm{~L}^{\circledR}$ (active ingredients Fludioxonil/Metalaxyl M) before sowing. The maize was sown with a density of 7 seeds $\mathrm{m}^{2}$ and the beans were sown in the two to three-leaf stage of maize at a distance of $0.125 \mathrm{~m}$ on either side of the maize row, also at a density of 7.0 seeds $\mathrm{m}^{2}$. The common bean cultivar "Preisgewinner", which is particularly suitable for maize bean intercropping [23], has been cultivated. Row spacing between maize plants was $0.75 \mathrm{~m}$.

Table 1. Management data of intercropped maize and bean for each experimental year. Pre-crop, type of tillage, sowing dates and densities of maize and bean, mineral fertilization, and harvest date.

\begin{tabular}{|c|c|c|c|}
\hline Management & 2017 & 2018 & 2019 \\
\hline Pre-crop & $\begin{array}{l}\text { Cauliflower (Brassica } \\
\text { oleracea L. var. botrytis) }\end{array}$ & $\begin{array}{c}\text { Maize } \\
\text { (Zea mays L.) }\end{array}$ & $\begin{array}{c}\text { Maize } \\
\text { (Zea mays L.) }\end{array}$ \\
\hline Tillage & Plough & Plough & Plough \\
\hline \multicolumn{4}{|l|}{ Sowing maize } \\
\hline Date & 9 May & 2 May & 21 April \\
\hline Density (seeds $\mathrm{m}^{2}$ ) & 7 & 7 & 7 \\
\hline \multicolumn{4}{|l|}{ Sowing bean } \\
\hline Date & 7 June & 1 June & 22 May \\
\hline Density (seeds m²) & 7 & 7 & 7 \\
\hline \multicolumn{4}{|l|}{ Mineral fertilization } \\
\hline Nitrogen $\left(\mathrm{kg} \mathrm{ha}^{-1}\right)$ & 80 & 80 & 80 \\
\hline Potassium $\left(\mathrm{kg} \mathrm{ha}^{-1}\right)$ & 60 & 60 & 60 \\
\hline Harvest date & 1 September & 21 August & 4 September \\
\hline
\end{tabular}


The three experimental years (2017 to 2019) varied in weather conditions (Table 2). In 2017, the temperatures and the precipitation in the period between 1 April and 30 August correlated with the long-term average in Rostock (temperatures 1981 to 2010: $14.3{ }^{\circ} \mathrm{C}$; precipitation 1981 to 2010: $347 \mathrm{~mm}$ ). April and May 2018, however, marked the warmest temperatures ever recorded in this area and time of year. The ensuing period brought one of the greatest droughts in the climate history of Germany. On top of this, in July and August, one of the longest and most intense periods of heat was recorded. Similar to the exceptionally warm summer of 2018, the main parts of summer 2019 were also especially dry and hot.

Table 2. Environmental conditions (precipitation $(\mathrm{mm})$ ), mean temperature $\left({ }^{\circ} \mathrm{C}\right)$ at the sampling sites for each experimental year from 1 April to 30 August.

\begin{tabular}{cccc}
\hline & $\mathbf{2 0 1 7}$ & $\mathbf{2 0 1 8}$ & $\mathbf{2 0 1 9}$ \\
\hline Precipitation $(\mathrm{mm})$ & 345 & 131 & 233 \\
Mean temperature $\left({ }^{\circ} \mathrm{C}\right)$ & 14.5 & 16.6 & 15.5 \\
\hline
\end{tabular}

\subsection{Experimental Setup}

In each year, the experimental setup included a control, three chemical methods, and one mechanical method of weed control (Table 3). Treatments were repeated four times per weed control method. The size of the plots was $5 \times 1.5 \mathrm{~m}$. Except for the mechanical treatment, a completely randomized block design was established. Due to technical limits, the mechanical control plots were located in a row, however, directly located next to the randomized block design.

Table 3. Treatments, method of weed control, and phenological growth stages $(\mathrm{BBCH})$ of maize and bean at the treatment time.

\begin{tabular}{|c|c|c|c|}
\hline \multirow[t]{2}{*}{ Treatment } & \multirow[t]{2}{*}{ Weed Control Method } & \multicolumn{2}{|c|}{ Phenological Growth Stages (BBCH) } \\
\hline & & Maize & Bean \\
\hline Control & Control & - & - \\
\hline CHEM-PRE & $\begin{array}{l}\text { Chemical pre-emergence } \\
\text { herbicide application }\end{array}$ & 12 & - \\
\hline CHEM-POST & $\begin{array}{l}\text { Chemical post-emergence } \\
\text { herbicide application }\end{array}$ & - & 12 \\
\hline $\begin{array}{c}\text { CHEM } \\
\text { PRE/POST }\end{array}$ & $\begin{array}{l}\text { Chemical pre- and } \\
\text { post-emergence } \\
\text { herbicide application }\end{array}$ & 12 & 12 \\
\hline $\mathrm{MECH}-\mathrm{C}$ & Mechanical control & 12 & 12 \\
\hline
\end{tabular}

Three different chemical weed control methods were tested (Tables 3 and 4). Preemergence herbicides (active ingredients Dimethenamid-P + Pendimethalin) were applied at the two-leaf stage of maize (treatment CHEM-PRE). Cycloxydim (+adjuvant) was treated post-emergence at the two-leaf stage of the bean (treatment CHEM-POST). The treatment CHEM PRE/POST included chemical pre- and post-emergence herbicide application. In a further treatment, weeds were controlled twice mechanically (MECH-C) with a tined weeder (BBCH 12 maize), followed by a mechanical hoe with goosefoot sweeps (BBCH 16 maize, BBCH 12 beans). 
Table 4. Active ingredients, HRAC/WSSA code ${ }^{1}$, active ingredient content, and dose rates of the chemical herbicides treatments. ${ }^{1}$ Herbicide Mechanism of Action According to the Herbicide Resistance Action Committee (HRAC) and Weed Science Society of America (WSSA) classification.

\begin{tabular}{ccccc}
\hline Treatment & $\begin{array}{c}\text { Active } \\
\text { Ingredients }\end{array}$ & $\begin{array}{c}\text { HRAC/WSSA } \\
\text { Code }\end{array}$ & $\begin{array}{c}\text { Active Ingredient } \\
\text { Content (g L L) }\end{array}$ & $\begin{array}{c}\text { Dose Rate } \\
\text { (L ha }^{-1} \text { ) }\end{array}$ \\
\hline CHEM-PRE & $\begin{array}{c}\text { Dimethenamid-P }+ \\
\text { Pendimethalin } \\
\text { Cycloxydim }+ \\
\text { adjuvant }\end{array}$ & $3+15$ & $455+720$ & $2.8+1.4$ \\
\hline
\end{tabular}

\subsection{Data Collection}

Weeds were assessed at $\mathrm{BBCH} 12$ of the maize, immediately before the first weed control treatments to estimate the initial weed infestation (weed assessment 1). Herbicide and mechanical treatment efficacies were assessed after pre-emergence bean herbicide application (weed assessment 2). By that time, the chemical post-emergence treatment had yet to be applied. The treatment efficacy was further checked 14 days after the postemergence herbicide application (weed assessment 3 ).

The weed coverage (\%) was estimated in $1 \mathrm{~m}^{2}$ with four random replications per plot. The mean weed coverage (\%) for each treatment was calculated as the average of the means per repetition plot. Weeds were identified at the species (if possible) or genus level and counted on ten subplots of $0.1 \mathrm{~m}^{2}$ within each of these plots, which were cumulated to $1 \mathrm{~m}^{2}$.

The intercropped maize and bean were harvested as silage maize with its biomass yield being weighed directly on the field from two rows $(6 \mathrm{~m})$. Subsamples from the chopped biomass yield were dried $\left(60^{\circ} \mathrm{C}\right)$ to weight constancy, and then the dry matter was assessed.

\subsection{Statistical Analysis}

Differences in weed control between the treatments were tested with ANOVA and the non-parametric Kruskal-Wallis test [31].

Linear mixed models (LMM) were used to estimate the relationship between weed control treatments, weed coverage (\%), and yield, respectively. The models were completed with variable years as random factors.

The "weed coverage" model is:

$$
W C_{r j}=\mu+T R_{r j}+k_{j}+\varepsilon_{r j k}
$$

The "yield" model is:

$$
\mathrm{YI}_{\mathrm{rj}}=\mu+\mathrm{TR}_{\mathrm{rj}}+\mathrm{k}_{\mathrm{j}}+\varepsilon_{\mathrm{rjk}}
$$

where $W C_{r j}$ is the weed coverage and $Y I_{r j}$ the yield of repetition $r$ in year $j, T R$ is the fixed effect of weed control treatment on repetition $r$ in year $j . k$ is the random effect of the annual conditions in year $\mathrm{j}$, epsilon is the random error term.

Marginal and conditional r-squared (R2) values for LMMs are calculated based on [32]. Marginal $R^{2}$ provides the variance explained only by fixed effects and conditional $R^{2}$ provides the variance explained by the entire model, i.e., both fixed effects and random effects.

$R$ (version 3.6.3) was used for statistical analyses and scientific graphics [33]. The following R packages were included: "agricolae" (non-parametric Kruskal-Wallis test) [34], "Ime4" and "lmerTest" (mixed models) [26,35], "ggplot2" (graphs) [36], and "performance" (r-squared values) [37]. 


\section{Results}

\subsection{Weed Species before Weed Control}

The weed coverage was evenly distributed before the first weed control treatment (Supplementary Table S1). The weed species composition was typical for maize fields (Table 5). Dicotyledons dominated the weed communities. The species that occurred in each experimental year were Chenopodium spp., Lamium spp., Polygonum spp.

Galinsoga spp., Stellaria media L., Spergula arvensis L., and Veronica spp. were frequently found in 2017 and 2019. In each year, however, the monocotyledon Poa spp. was the dominant weed.

Table 5. Mean weed species density $\mathrm{m}^{-1}$ per experimental year (2017 to 2019) recorded before the first weed control treatment.

\begin{tabular}{ccccc}
\hline Weed Species & EPPO Code & \multicolumn{3}{c}{${\text { Plant Density } \mathbf{~}^{-\mathbf{1}}}$} \\
\hline & & $\mathbf{2 0 1 7}$ & $\mathbf{2 0 1 8}$ & $\mathbf{2 0 1 9}$ \\
\hline $\begin{array}{c}\text { Monocotyledon } \\
\text { Poa spp. }\end{array}$ & POASS & 35 & & 78 \\
Dicotyledons & & & & \\
Capsella bursa-pastoris & CAPBP & 18 & - & 6 \\
Chenopodium spp. & CHESS & 14 & 7 & 69 \\
Galinsoga spp. & GASSS & 15 & - & 86 \\
Lamium spp. & LAMSS & 20 & 12 & 37 \\
Matricaria spp. & MATSS & - & - & 4 \\
Polygonum spp. & POLPE & 25 & 20 & 15 \\
Stellaria media & STEME & 12 & - & 42 \\
Spergula arvensis & SPRAR & 14 & - & 12 \\
Thlaspi arvense & THLAR & - & - & 25 \\
Veronica spp. & VERSS & 12 & - & \\
\hline
\end{tabular}

\subsection{Weed Coverage in the Treatments}

Weed assessment 2 (after the pre-emergence bean herbicide application) revealed significant differences in weed coverage (\%) among the treatments (Figure 2a-c).

In each experimental year, the highest weed coverage was recorded for the control and POST-EM treatments. In 2017, no significant differences in weed coverage were found between the MECH-C and CHEM-PRE/POST treatments. Across all treatments, the CHEM-PRE resulted in the significantly lowest weed coverage. In 2018, the levels of weed coverage for the treatments MECH-C, CHEM-PRE, and CHEM-PRE/POST were uniform. In 2019, weed coverage was lowest for the CHEM-PRE/POST treatment, followed by weed coverage of the treatments MECH-C and CHEM-PRE.

In weed assessment 3 (14 days after the post-emergence herbicide application), the average weed coverage of all treatments increased compared to weed assessment 2 . In 2017 and 2019, the weed coverage was significantly lowest for the CHEM-PRE/POST treatment. In 2018, treatments MECH-C, CHEM-PRE, and CHEM-PRE/POST resulted in similar levels of weed coverage. 

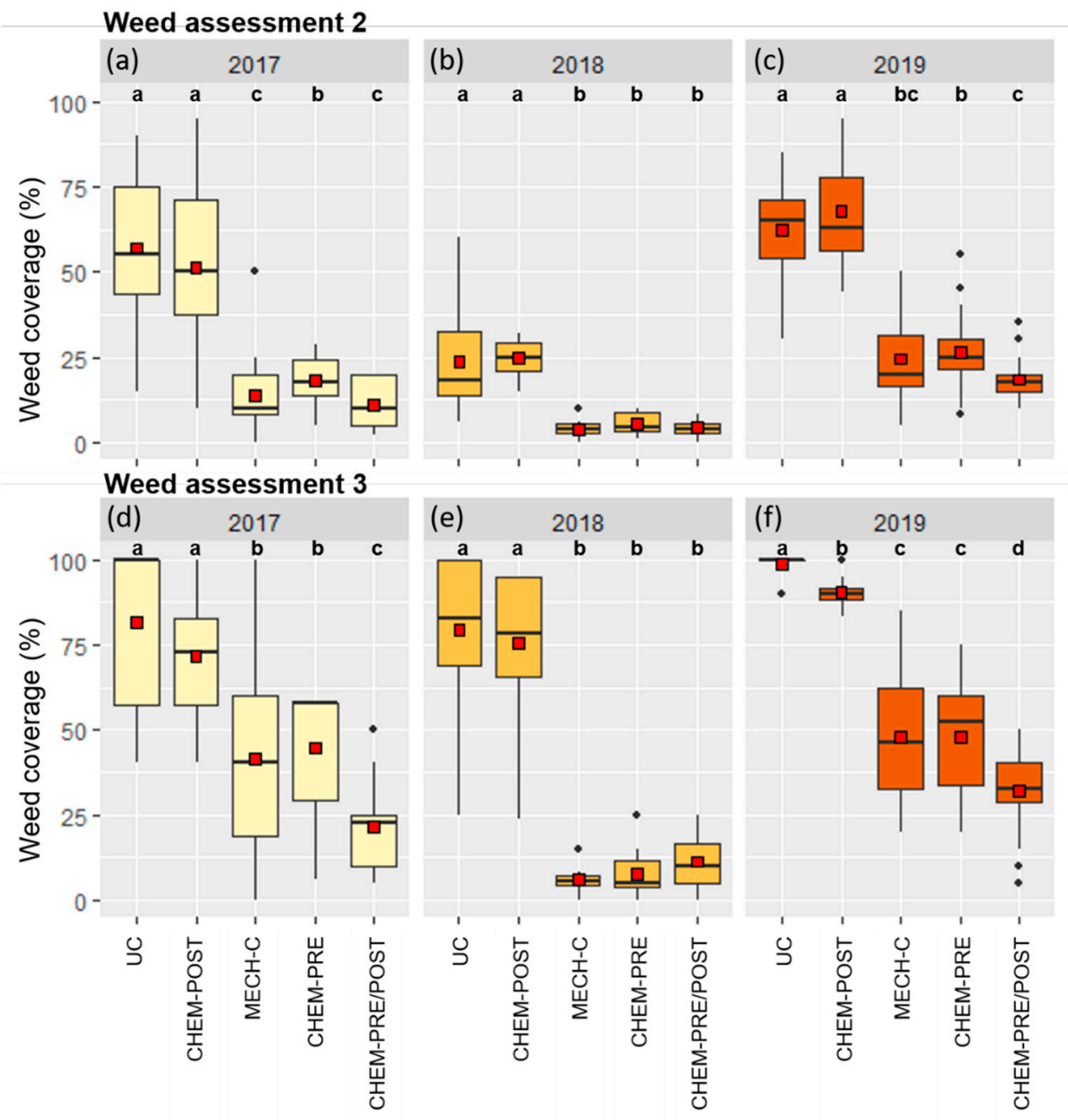

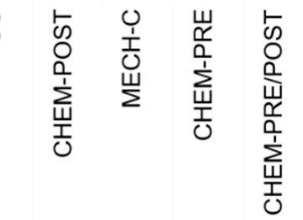

Figure 2. Weed coverage (\%) for the different methods of weed control in 2017 to 2019. (a-c): Weed assessment 2 (after the pre-emergence bean herbicide application). (d-f): Weed assessment 3 (14 days after the post-emergence herbicide application). Kruskal-Wallis Test: different letters represent significant differences $(p<0.05)$ between the different methods of weed control.

\subsection{Weed Control Effect}

Results for the "weed coverage" model are given in Table 6 . The model explains $72 \%$ of the total variation (conditional $\mathrm{R}^{2}=0.72$ ). Fixed factors accounted for $56 \%$ of the model's explained variation (marginal $R^{2}=0.56$ ).

In general, weed control significantly decreased the mean weed coverage (\%) of intercropped maize and bean compared to the control. Weed coverage was reduced by up to $75.3 \%$ using the CHEM-PRE/POST treatment and by up to $60.7 \%$ through mechanical weed control, compared to the control.

The single post-emergence herbicide effect (CHEM-POST) accounts for $8.6 \%$ relative to the control. The additional effect of post-emergence treatment on the pre-emergence herbicide control resulted in a $16.5 \%$ weed coverage decline (Table 6). 
Table 6. Regression: effect of weed control treatments on weed coverage (\%). The proportion of the model's explained variance and significance (F-test). Marginal $\mathrm{R}^{2}$ provides the variance explained only by fixed effects and conditional $\mathrm{R}^{2}$ provides the variance explained by the entire model, i.e., both fixed effects and random effects.

\begin{tabular}{cccc}
\hline & Estimate & $\mathbf{P}(\mathbf{t})$ & Effect Relative to the Control (\%) \\
\hline $\begin{array}{c}\text { Mean weed coverage (\%) of control } \\
\text { Difference to the control }\end{array}$ & 85.5 & $0.0041^{* *}$ & \\
CHEM-POST & -7.9 & $0.0357^{* *}$ & -8.6 \\
MECH-C & -51.9 & $<2 \mathrm{e}-16^{* * *}$ & -60.7 \\
CHEM-PRE & -50.3 & $<2 \mathrm{e}-16^{* * *}$ & -58.8 \\
CHEM-PRE/POST & -64.4 & $<2 \mathrm{e}-16^{* * *}$ & -75.3 \\
\hline Fitting quality of the model & & & \\
Conditional $\mathrm{R}^{2}$ & 0.72 & & \\
Marginal $\mathrm{R}^{2}$ & 0.56 & & \\
\hline$* p<0.05^{* *} p<0.01^{* * *} p<0.001$ & &
\end{tabular}

\subsection{Crop Productivity}

Intercropped maize and bean yield significantly differ between the different methods of weed control (Figure 3). In each experimental year, significant treatment effects on dry matter (DM) yield ( $\mathrm{t} \mathrm{ha}^{-1}$ ) occurred. Across all years, the DM yield of the treatment CHEM-PRE/POST was significantly the highest. In 2017, DM yield of the treatments CHEM-PRE/POST and CHEM-PRE did not differ significantly among each other. The MECH-C treatment achieved a significantly higher DM yield compared to the DM yield of the control and POST-EM treatments. In 2018, DM yield differences among treatments were not statistically significant except for the CHEM-PRE/POST treatment. DM yields of MECH-C and CHEM-PRE treatments did not significantly differ in 2019. The CHEM-PRE treatment DM yields were significantly higher than the DM yield of the control.
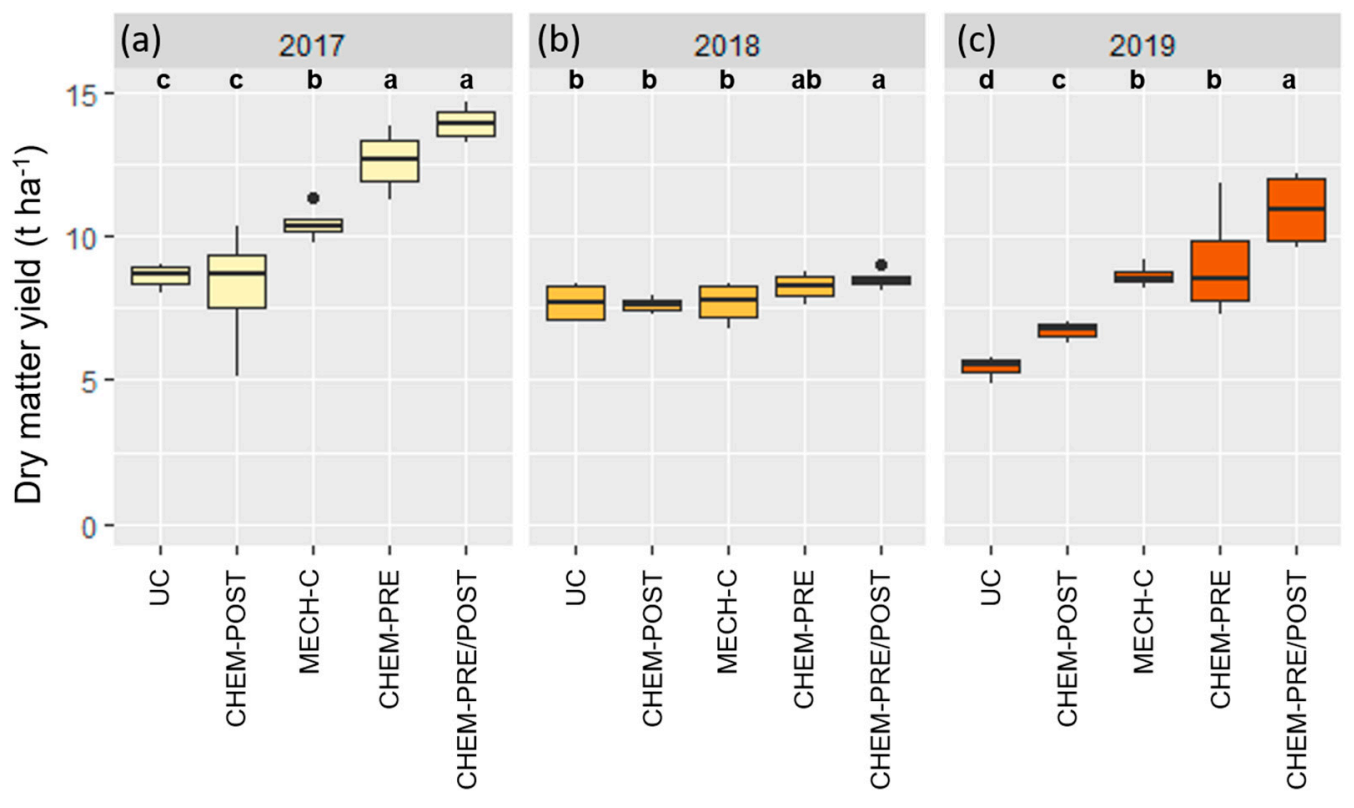

Figure 3. Yield ( $\mathrm{t} \mathrm{ha}^{-1}$ ) comparison between the different methods of weed control. Results for (a) 2017, (b) 2018 and (c) 2019. Kruskal-Wallis test: different letters represent significant differences $(p<0.05)$ between the different methods of weed control. Supplementary Table S2: Dry matter content (\%) of different methods of weed control.

Results for the "yield" model are presented in Table 7. The models fit well and explain $73 \%$ of the variance (conditional $\mathrm{R}^{2}=0.73$ ). The fixed effect (weed control) accounts for $35 \%$ of the variance explained by the model (marginal $R^{2}=0.35$ ). Compared to the 
control, the yield surplus of the treatment CHEM-PRE/POST was 53.4\%, for the MECH-C treatment $22.9 \%$, respectively. The additional effect of post-emergence measurements on the pre-emergence herbicide control resulted in a $16.1 \%$ yield surplus compared to the single pre-emergence chemical weed control (Table 7).

Table 7. Regression: effect of weed control treatments on yield ( $\left.\mathrm{t} \mathrm{ha}{ }^{-1}\right)$. The proportion of the model's explained variance and significance (F-test). Marginal $\mathrm{R}^{2}$ provides the variance explained only by fixed effects and conditional $\mathrm{R}^{2}$ provides the variance explained by the entire model, i.e., both fixed effects and random effects.

\begin{tabular}{|c|c|c|c|}
\hline & Estimate & $\mathbf{P}(\mathbf{t})$ & Effect Relative to the Control (\%) \\
\hline $\begin{array}{l}\text { Mean yield ( } \mathrm{t} \mathrm{ha}^{-1} \text { ) of control } \\
\text { Difference to the control }\end{array}$ & 7.23 & $0.00800^{* *}$ & \\
\hline CHEM-POST & +0.27 & 0.60517 & +3.7 \\
\hline MECH-C & +1.66 & $0.00286^{* *}$ & +22.9 \\
\hline CHEM-PRE & +2.70 & $4.59 \mathrm{e}-06^{* * *}$ & +37.3 \\
\hline CHEM-PRE/POST & +3.86 & $1.59 \mathrm{e}-09^{* * *}$ & +53.4 \\
\hline \multicolumn{4}{|l|}{ Fitting quality of the model } \\
\hline Conditional $\mathrm{R}^{2}$ & 0.73 & & \\
\hline Marginal $\mathrm{R}^{2}$ & 0.35 & & \\
\hline
\end{tabular}

\section{Discussion}

This study expands the understanding of weed control strategies in intercropped maize and bean. The three-year field experiments revealed further options for weed management in a maize and bean mixture. Weed species composition is generally associated with farmers' management strategies [38], the weed suppression effect of the cultivated crop [39,40], and environmental conditions [41]. The results of this study confirm the major effect of environmental factors on weed infestation and dry matter yields of maize and bean mixtures. Particularly, in 2018, the experiment was strongly affected by unusual weather conditions, which were characterized by longer periods of drought and strongly reduced rainfall. Nevertheless, the effects of the treatments on weed control and crop productivity in intercropped maize and bean are similar among the three experimental years.

The most successful weed control strategy was the chemical pre- and post-emergence herbicide application (Figure 2). Weed coverage was reduced by up to $75.3 \%$ using the CHEM-PRE/POST treatment. The application of pre-emergence herbicides is an established method to control the infestation of weeds in a maize and bean mixture [25,27]. The active ingredients Dimethenamid-P and Pendimethalin effectively control a wide range of annual grass and annual broad-leaved weeds during an early sensitive stage of maize development [42-45]. Nevertheless, when the herbicide activity declines, new-emerging weeds occur and postemergence herbicides must be applied for optimal weed control as they can also be competitive. In this study, therefore, herbicides were also applied after the emergence of the bean. This type of weed control is not an established method in intercropped maize and bean cultivation due to the limited chemical herbicide options. The registered active ingredient Cycloxydim has a broad spectrum of activity against monocot weeds but remains largely ineffective against dicotyl weeds. The additional effect of post-emergence treatment on the pre-emergence herbicide control resulted in a $16.5 \%$ weed coverage decline (Table 6). Particularly, the weed coverage results in 2017 and 2018 (Figure $2 \mathrm{~d}, \mathrm{f}$ ) confirm the additional effects of the post-emergence herbicide application on the overall herbicide efficacy of the treatment CHEM-PRE/POST. The additional effect of post-emergence measurements on the pre-emergence herbicide control was confirmed by [27]. The mentioned study combined a pre-emergence herbicide application of the active ingredient pendimethalin followed by one mechanical rotary hoeing.

For the single post-emergence treatment (CHEM-POST) with the active ingredient Cycloxydim, the efficacy was significantly reduced. In each experimental year, the weed 
coverage of the CHEM-POST treatment at the post-emergence application date was already particularly high (Figure 2). It is probable that the broad-leaved weeds covered the monocotyledons and, therefore, the grass weeds have not been controlled. Hence, these results suggest that the active ingredient Cycloxydim should be used to control monocot weeds, while a broadly effective herbicide has already been applied at an earlier stage of maize development.

The results further confirmed that the type of weed control has a significant effect on the weed coverage (Figure 2). Optimal timing of weed control during the most sensitive stage of maize development is crucial for the establishment of a maize and bean mixture when weed control is done mechanically. Purely mechanical weed control (treatment $\mathrm{MECH}-\mathrm{C}$ ) resulted in significantly lower weed coverage in the maize and bean mixture compared to the control and chemical post-emergence control (Table 6). At the final weed assessment in 2017 and 2018, 14 days after the last treatments, the MECH-C treatment led to no significant difference in weed coverage compared to the treatment CHEM-PRE. Hence, in the mechanical treatment, weeds were controlled twice mechanically (BBCH 12 maize and $\mathrm{BBCH} 16$ maize/BBCH 12 beans), whereas the chemical pre-emergence herbicide application is a single weed control measurement in $\mathrm{BBCH} 12$ of the maize. Moreover, in 2018, the mechanical treatment MECH-C obtained the same low weed coverage as both chemical treatments (Figure 2e), and hereby, provided sufficient weed control. The possibilities for using mechanical tools for in-crop cultivation depend particularly on field and weather conditions [46]. Obviously, the dry weather conditions in 2018 highly promoted the effectiveness of the mechanical weed control treatment.

The control of early-emerging weeds is essential to protect the yield potential of conventional monoculture maize [47], likewise for the maize bean mixture [25]. In all three experimental years, the DM yield of the treatment CHEM-PRE/POST was significantly the highest (Figure 3). The additional effect of post-emergence measurements on preemergence herbicide control resulted in a 3 to $17 \%$ yield surplus (Table 7). Compared to the control, the yield surplus of the treatment CHEM-PRE/POST was $53.4 \%$.

The DM yield significantly increased with the higher weed control efficacy of the treatments (Figure 3, Table 7). Nevertheless, for all three experimental years, the DM yields of the intercropped maize and bean performed badly in all treatments. Generally, the total yield in intercropped maize and bean is comparable with that of pure maize stands [23]. In this study, the yields of the mixture were much lower than the regional mean silage maize yields in northeast Germany [48]. From an experimental setup view, the fertilization management of the mixture surely limited the DM yields. High soil phosphorus $(\mathrm{P})$ levels are essential to obtain high maize yields. Generally, phosphorus will be applied broadcast or as banded fertilization in intercropped maize and bean. The results of this study underline that $\mathrm{P}$ fertilizer is a major concern for producers striving to achieve maximum economic yield. Besides, in 2018 and 2019, the low DM yields of the mixture were probably highly influenced by the dry weather conditions in spring and summer. Excluding environmental variables, yield losses in maize are further mainly caused by competition from weeds [49]. For maize bean mixtures, a weed coverage of up to $10 \%$ may be tolerated, without a large yield reduction [25]. Hence, the higher weed coverages of all treatments in 2017 and 2019 might probably have limited the maize and bean mixture yield.

\section{Conclusions}

Optimal timing of weed control during the most sensitive phenology stages of the maize and bean mixture is crucial for productivity. The results of this study provide an additional option for suitable weed control for intercropped maize and bean. By further optimizing the weed control through using post-emergence herbicides, maize and bean mixtures might probably present an alternative to the monoculture of maize. Thus, intercropping of maize and bean might be one option of sustainable systems' intensification in European arable farming. 
Agriculture in the European Union is currently in a phase characterized by the transition from conventional to Integrated Pest Management (IPM) systems (European Directive $128 / 2009$ ), as well as by the withdrawal of products and restriction on the use of pesticides. The previous results confirm that mechanical weed control may reduce the reliance on chemical herbicides in intercropped maize and bean.

Supplementary Materials: The following are available online at https:/ /www.mdpi.com/article/ 10.3390/agriculture11050380/s1, Table S1: Mean weed coverage and standard deviation (sd) of the treatments before herbicide application 2017 to 2019. In each year, we did not analyze significant differences $(p<0.05)$ in weed coverage between the treatments. Kruskal-Wallis Test. Table S2: Mean dry matter content $(\%)$ and standard deviation (sd) of the treatments.

Funding: This research received no external funding.

Acknowledgments: I would like to express my warm thanks to Jessica Constapel for supporting me over the last few painful months. I also gratefully thank Maike Schneider for giving her English expertise.

Conflicts of Interest: The author declares no conflict of interest.

\section{References}

1. Rose, S.K.; Kriegler, E.; Bibas, R.; Calvin, K.; Popp, A.; van Vuuren, D.P.; Weyant, J. Bioenergy in energy transformation and climate management. Clim. Chang. 2014, 123, 477-493. [CrossRef]

2. Thrän, D.; Schaubach, K.; Majer, S.; Horschig, T. Governance of sustainability in the German biogas sector-Adaptive management of the Renewable Energy Act between agriculture and the energy sector. Energy Sustain. Soc. 2020, 10. [CrossRef]

3. Herrmann, A. Biogas Production from Maize: Current State, Challenges and Prospects. 2. Agronomic and Environmental Aspects. Bioenerg. Res. 2013, 6, 372-387. [CrossRef]

4. Kalač, P. The required characteristics of ensiled crops used as a feedstock for biogas production: A review. J. Agrobiol. 2011, 28, 85-96. [CrossRef]

5. Reynolds, T.W.; Waddington, S.R.; Anderson, C.L.; Chew, A.; True, Z.; Cullen, A. Environmental impacts and constraints associated with the production of major food crops in Sub-Saharan Africa and South Asia. Food Sec. 2015, 7, 795-822. [CrossRef]

6. Stoate, C.; Boatman, N.D.; Borralho, R.J.; Carvalho, C.R.; Snoo, G.R.; de Eden, P. Ecological impacts of arable intensification in Europe. J. Environ. Manag. 2001, 63, 337-365. [CrossRef] [PubMed]

7. Betencourt, E.; Duputel, M.; Colomb, B.; Desclaux, D.; Hinsinger, P. Intercropping promotes the ability of durum wheat and chickpea to increase rhizosphere phosphorus availability in a low P soil. Soil Biol. Biochem. 2012, 46, 181-190. [CrossRef]

8. Hauggaard-Nielsen, H.; Jørnsgaard, B.; Kinane, J.; Jensen, E.S. Grain legume-cereal intercropping: The practical application of diversity, competition and facilitation in arable and organic cropping systems. Renew. Agric. Food Syst. 2008, 23, 3-12. [CrossRef]

9. Seran, T.; Brintha, I. Review on Maize Based Intercropping. J. Agron. 2010, 9, 135-145. [CrossRef]

10. Eichler-Löbermann, B.; Gaj, R.; Schnug, E. Improvement of Soil Phosphorus Availability by Green Fertilization with Catch Crops. Commun. Soil Sci. Plan. 2009, 40, 70-81. [CrossRef]

11. Liebman, M.; Dyck, E. Crop Rotation and Intercropping Strategies for Weed Management. Ecol. Appl. 1993, 3, 92-122. [CrossRef]

12. Neumann, A.; Schmidtke, K.; Rauber, R. Effects of crop density and tillage system on grain yield and $\mathrm{N}$ uptake from soil and atmosphere of sole and intercropped pea and oat. Field Crops Res. 2007, 100, 285-293. [CrossRef]

13. Nassary, E.K.; Baijukya, F.; Ndakidemi, P.A. Productivity of intercropping with maize and common bean over five cropping seasons on smallholder farms of Tanzania. Eur. J. Agron. 2020, 113, 125964. [CrossRef]

14. Giller, K.E. Nitrogen Fixation in Tropical Cropping Systems, 2nd ed.; CABI Pub: Wallingford, Oxon, UK; New York, NY, USA, 2001; ISBN 9780851994178.

15. Bybee-Finley, K.; Ryan, M. Advancing Intercropping Research and Practices in Industrialized Agricultural Landscapes. Agriculture 2018, 8, 80. [CrossRef]

16. Nurk, L.; Graß, R.; Pekrun, C.; Wachendorf, M. Methane Yield and Feed Quality Parameters of Mixed Silages from Maize (Zea mays L.) and Common Bean (Phaseolus vulgaris L.). Bioenergy Res. 2017, 10, 64-73. [CrossRef]

17. Fischer, C.; Thies, C.; Tscharntke, T. Mixed effects of landscape complexity and farming practice on weed seed removal. Perspect. Plant Ecol. Evol. Syst. 2011, 13, 297-303. [CrossRef]

18. Bedoussac, L.; Journet, E.-P.; Hauggaard-Nielsen, H.; Naudin, C.; Corre-Hellou, G.; Jensen, E.S.; Prieur, L.; Justes, E. Ecological principles underlying the increase of productivity achieved by cereal-grain legume intercrops in organic farming. A review. Agron. Sustain. Dev. 2015, 35, 911-935. [CrossRef]

19. Latati, M.; Bargaz, A.; Belarbi, B.; Lazali, M.; Benlahrech, S.; Tellah, S.; Kaci, G.; Drevon, J.J.; Ounane, S.M. The intercropping common bean with maize improves the rhizobial efficiency, resource use and grain yield under low phosphorus availability. Eur. J. Agron. 2016, 72, 80-90. [CrossRef] 
20. Eure, P.M.; Culpepper, A.S.; Merchant, R.M.; Roberts, P.M.; Collins, G.C. Weed Control, Crop Response, and Profitability When Intercropping Cantaloupe and Cotton. Weed Technol. 2015, 29, 217-225. [CrossRef]

21. Verret, V.; Gardarin, A.; Pelzer, E.; Médiène, S.; Makowski, D.; Valantin-Morison, M. Can legume companion plants control weeds without decreasing crop yield? A meta-analysis. Field Crops Res. 2017, 204, 158-168. [CrossRef]

22. Wezel, A.; Casagrande, M.; Celette, F.; Vian, J.-F.; Ferrer, A.; Peigné, J. Agroecological practices for sustainable agriculture. A review. Agron. Sustain. Dev. 2014, 34, 1-20. [CrossRef]

23. Fischer, J.; Böhm, H.; He $\beta$, J. Maize-bean intercropping yields in Northern Germany are comparable to those of pure silage maize. Eur. J. Agron. 2020, 112, 125947. [CrossRef]

24. Federal Office of Consumer Protection and Food Safety. Online Data Base on Plant Protection Products. Available online: https:/ / apps2.bvl.bund.de/psm/jsp/index.jsp (accessed on 14 January 2021).

25. Nurk, L.; Graß, R.; Pekrun, C.; Wachendorf, M. Effect of Sowing Method and Weed Control on the Performance of Maize (Zea mays L.) Intercropped with Climbing Beans (Phaseolus vulgaris L.). Agriculture 2017, 7, 51. [CrossRef]

26. Bates, D.; Mächler, M.; Bolker, B.; Walker, S. Fitting Linear Mixed-Effects Models Usinglme4. J. Stat. Softw. 2015, 67, 1-48. [CrossRef]

27. Rajeshkumar, A.; Venkataraman, N.S.; Ramadass, S.; Ashokkumar, N.; Thirumeninathan, S. In this context, weed control is an important issue in intercropping, as chemical control is challenging. Generally, intercropping a dicotyledonous crop with a monocotyledonous crop reduces herbicide options. J. Crop Weed 2011, 13, 150-155.

28. Yamazaki, D.; Ikeshima, D.; Tawatari, R.; Yamaguchi, T.; O’Loughlin, F.; Neal, J.C.; Sampson, C.C.; Kanae, S.; Bates, P.D. A high-accuracy map of global terrain elevations. Geophys. Res. Lett. 2017, 5844-5853. [CrossRef]

29. Muasya, R.M.; Lommen, W.; Muui, C.; Struik, P.C. How weather during development of common bean (Phaseolus vulgaris L.) affects the crop's maximum attainable seed quality. NJAS Wagening. J. Life Sci. 2008. [CrossRef]

30. Destatis. Land-und Forstwirtschaft, Fischerei Wachstum und Ernte-Feldfrüchte. 2018. Available online: https://www. destatis.de/DE/Themen/Branchen-Unternehmen/Landwirtschaft-Forstwirtschaft-Fischerei/Feldfruechte-Gruenland/ Publikationen/Downloads-Feldfruechte/feldfruechte-jahr-2030321187164.pdf?_blob=publicationFile\&v=3 (accessed on 19 April 2021).

31. Kruskal, W.H.; Wallis, W.A. Use of Ranks in One-Criterion Variance Analysis. J. Am. Stat. Assoc. 1952, 583. [CrossRef]

32. Nakagawa, S.; Johnson, P.C.D.; Schielzeth, H. The coefficient of determination R2 and intra-class correlation coefficient from generalized linear mixed-effects models revisited and expanded. J. R. Soc. Interface 2017. [CrossRef]

33. R Core Team. R: A Language and Environment for Statistical Computing; R Foundation for Statistical Computing: Vienna, Austria, 2020. Available online: https:/ / www.R-project.org/ (accessed on 19 April 2021).

34. de Mendiburu, F.; Yaseen, M. Agricolae: Statistical Procedures for Agricultural Research. R package Version 1.4.0; 2020. Available online: https:/ / myaseen208.github.io/agricolae/ (accessed on 19 April 2021).

35. Kuznetsova, A.; Brockhoff, P.B.; Christensen, R.H.B. lmerTest Package: Tests in Linear Mixed Effects Models. J. Stat. Softw. 2017, 82, 1-26. [CrossRef]

36. Wickham, H. ggplot2: Elegant Graphics for Data Analysis; Springer: New York, NY, USA, 2016.

37. Lüdecke, D.; Ben-Shachar, M.S.; Patil, I.; Waggoner, P.; Makowski, D. Assessment, Testing and Comparison of Statistical Models using R. J. Open Source Softw. 2021, 3112. [CrossRef]

38. Fried, G.; Norton, L.R.; Reboud, X. Environmental and management factors determining weed species composition and diversity in France. Agric. Ecosyst. Environ. 2008, 128, 68-76. [CrossRef]

39. Andreasen, C.; Skovgaard, I.M. Crop and soil factors of importance for the distribution of plant species on arable fields in Denmark. Agric. Ecosyst. Environ. 2009, 133, 61-67. [CrossRef]

40. Pinke, G.; Karácsony, P.; Czúcz, B.; Botta-Dukát, Z.; Lengyel, A. The influence of environment, management and site context on species composition of summer arable weed vegetation in Hungary. Appl. Veg. Sci. 2012, 15, 136-144. [CrossRef]

41. de Mol, F.; Redwitz, C.; von Gerowitt, B. Weed species composition of maize fields in Germany is influenced by site and crop sequence. Weed Res. 2015, 55, 574-585. [CrossRef]

42. Jursík, M.; Soukup, J.; Holec, J.; Andr, J.; Hamouzová, K. Efficacy and selectivity of pre-emergent sunflower herbicides under different soil moisture conditions. Plant Protect. Sci. 2016, 51, 214-222. [CrossRef]

43. Idziak, R.; Woznica, Z. Efficacy of Reduced Rates of Soil-Applied Dimethenamid-P and Pendimethalin Mixture Followed by Postemergence Herbicides in Maize. Agriculture 2020, 10, 163. [CrossRef]

44. Janak, T.W.; Grichar, W.J.; Serrano, M. Weed Control in Corn (Zea mays L.) as Influenced by Preemergence Herbicides. Int. J. Agron. 2016, 2016, 2607671. [CrossRef]

45. Andr, J.; Hejnák, V.; Jursík, M.; Fendrychová, V. Effects of application terms of three soil active herbicides on herbicide efficacy and reproductive ability for weeds in maize. Plant Soil Environ. 2014, 60, 452-458. [CrossRef]

46. van der Weide, R.Y.; Bleeker, P.O.; Achten, V.T.J.M.; Lotz, L.A.P.; Fogelberg, F.; Melander, B. Innovation in mechanical weed control in crop rows. Weed Res. 2008, 48, 215-224. [CrossRef]

47. Page, E.R.; Cerrudo, D.; Westra, P.; Loux, M.; Smith, K.; Foresman, C.; Wright, H.; Swanton, C.J. Why Early Season Weed Control Is Important in Maize. Weed Sci. 2012, 60, 423-430. [CrossRef]

48. German Maize Committee. Silage Maize Yields (Incl. Biogas Use) in Germany, 2015-2019, by Federal State. Available online: https:/ / www.maiskomitee.de/Fakten/Statistik/Deutschland/Fl\%C3\%A4chenertr\%C3\%A4ge (accessed on 25 February 2021). 
49. Rajcan, I.; Swanton, C.J. Understanding maize-weed competition: Resource competition, light quality and the whole plant. Field Crops Res. 2001, 71, 139-150. [CrossRef] 